University of Nebraska - Lincoln

DigitalCommons@University of Nebraska-Lincoln

Textile Society of America Symposium

Proceedings

Textile Society of America

2020

Wool Sells Itself: tracing the movement of Navajo-raised wools

Emily Winter

Follow this and additional works at: https://digitalcommons.unl.edu/tsaconf

Digitalrt of the Art and Materials Conservation Commons, Art Practice Commons, Fashion Design

Commens, Fiber, Textile, and Weaving Arts Commons, Fine Arts Commons, and the Museum Studies

detwerkns

Logo

This Article is brought to you for free and open access by the Textile Society of America at

DigitalCommons@University of Nebraska - Lincoln. It has been accepted for inclusion in Textile Society of America

Symposium Proceedings by an authorized administrator of DigitalCommons@University of Nebraska - Lincoln. 
Published in Hidden Stories/Human Lives: Proceedings of the Textile Society of America 17th Biennial Symposium, October 15-17, 2020. https://digitalcommons.unl.edu/tsaconf/

\title{
Wool Sells Itself: tracing the movement of Navajo-raised wools
}

\author{
Emily Winter
}

This presentation and paper are part of a larger work-in-progress which aims to make visible some of the places, people, and processes that constitute a segment of the domestic wool supply chain. I am focusing on wools raised by Navajo producers as these are wools that I work with and it is a supply chain that I have direct contact with and access to. As a weaver who makes and sells textiles from wool connected to this supply chain and as someone who is committed to the practice of understanding the capitalist modes of production which shape the way we relate to objects, I have a vested interest in finding methods of describing these material pathways that transcend the marketing rhetoric of transparency and traceability. The impulse towards transparency in production, while commendable, only takes one so far. This project is an attempt to articulate the relationships of history, labor, power, and landscape to the textiles we make and live with - these intangible things which are always present in materials, but whose specificity is lost through the process of exchange.

\section{THE WOOL BUY: WHERE IT CAME FROM}

The Wool Buy began in 2012 with a partnership between Black Mesa Water Coalition, a NavajoHopi environmental justice organization, ${ }^{1}$ and Mid-States Wool Growers Cooperative, an Ohiobased commercial wool warehouse. Black Mesa had begun the Navajo Wool Market Improvement Project, working to identify better marketing opportunities for Diné (Navajo) wool and promote traditional wool processing and weaving practices. As it stood, the main outlet for Navajo to sell their wool on the reservation was at trading posts or border town livestock depots, which paid a nominal 5 to 25 cents a pound, taking little account of the type or quality of wool. These prices were untethered from both the labor of raising the wool and price fluctuations in the broader (off-reservation) wool market. In 2012, Roberto Nutlouis of Black Mesa invited Stanley Strode from Mid-States to come out to the reservation to buy wool in the hopes of increasing prices for producers by putting them in direct contact with buyers. That first summer, Mid-States bought about 12,000 pounds of wool from producers in Pinon, Arizona. Stanley came back the following year, adding a few more towns to the route. In subsequent years, buyers from Peace Fleece (now a part of Harrisville Designs) joined the caravan, as did Teddy Varndell, an independent mohair buyer from Chicago. By June 2019, the Wool Buy had grown into a weeklong affair organized by Black Mesa, Mid-States and the Diné College Land Grant Office. Over the course of one week in June, the caravan of buyers, workers and volunteers criss-crossed the Navajo Nation buying over 160,000 pounds of wool from producers at nine different sites.

Sheep and wool have long been a part of Navajo culture and economy. The Diné people had been living in Dinétah (the Navajo homeland, covering parts of modern-day New Mexico, Arizona, Utah) for over a century when Spanish colonists arrived in the late 1500s, bringing with them large numbers of sheep, goats, and cattle. By the end of the $17^{\text {th }}$ century, sheep and wool

\footnotetext{
${ }^{1}$ Founded in 2001 in response to Peabody Coal's mining activities in the Black Mesa region, BMWC ran a number of programs from 2001-2020 focused on developing a restorative economy in the Navajo Nation, in opposition to the extraction economies (coal and uranium) which have dominated the region in the $20^{\text {th }}$ century. In the summer of 2020, they merged with another organization and some of their programs have been paused since.
} 
had taken their place as integral components of Diné pastoralism and cosmology. ${ }^{2}$ The churro sheep, descended from the Spanish churra, evolved over the next several centuries in relation to the demands of Navajo life. Their fleeces were low in grease, making them easy to process by hand, their color gradation offered an expansive palette for Diné weavers, they were hardy and resilient, their meat was tasty. From the $16^{\text {th }}-19^{\text {th }}$ centuries, Diné existed in a cycle of trade and territorial tension with neighboring Puebloan peoples, Spanish settlers, Mexican ranchers, and other Native peoples, often involving the raiding and capture of livestock. The cycle of violence intensified in the 1840s, as the U.S. Army expanded westwards into New Mexico. In 1863, as the culmination of a process of Indian removal and confinement, U.S. Army troops began the Long Walk, the violent and forced relocation of Diné people from their homes to Bosque Redondo, a camp in Southeastern New Mexico. In the process, many Diné were killed, farms destroyed, and livestock seized by the U.S. government. The internment at Bosque Redondo was a humanitarian and logistical disaster, with many Diné dying of starvation. In 1868, the Treaty of Bosque Redondo was signed, establishing the boundaries of the modern-day reservation which covered about one quarter of the land previously occupied by the Diné. The establishment of the reservation marked the beginning of a new era in Navajo history, one marked by the settler colonial state's geographic, economic and cultural circumscription of Diné life.

In the years following the establishment of the reservation, Bureau of Indian Affairs (BIA) agents encouraged livestock development as a means of integrating with the national economy and establishing agricultural self-sufficiency. ${ }^{3}$ Trading posts sprouted up within the reservation and around its borders, serving as the primary resource for Navajo to obtain basic goods and trade wool and textiles. With the arrival of the Atlantic \& Pacific Railroad in 1881, trading posts grew even more robust in their wholesale business while export of Navajo-raised wool and woven textiles to markets back East expanded. ${ }^{4}$ Prior to the Civil War, most wool in the U.S. was produced on farms in the East. The expansion of the railroad into the American West opened up rangelands which transformed the nature of sheep raising and wool marketing. The territorial expansiveness and the arid climate meant it was far less expensive to raise sheep on large ranches in the West than on the smaller diversified farms of the East. The development of a trading post wool economy in the Navajo Nation fit into this broader trend, with the added complexity that grazing and water access were restricted by the reservation's boundaries, thereby limiting the potential for Navajo to produce wool much beyond a subsistence scale. As domestic wool prices fluctuated in the late 19th century, Diné increasingly turned to woven textiles over raw wool as an item of trade. By the beginning decades of the $20^{\text {th }}$ century, Diné livestock numbers had returned to something approaching their pre-1860s levels. ${ }^{5}$

\footnotetext{
${ }^{2}$ According to Diné cosmology, livestock preceded the Diné themselves and the Diné of course preceded the Spanish. See Chapter 3 of Dreaming of Sheep in Navajo Country for a nuanced discussion of the relation of Diné cosmology to Western historical modes/analytical thinking.

Marsha Weisiger, Dreaming of Sheep in Navajo Country, (Seattle: University of Washington Press, 2009), 63-78.

${ }^{3}$ Weisiger, 22.

${ }^{4}$ See the following for more in-depth examination of trading post politics, economics, and trading patterns:

Frank McNitt. The Indian Traders. Norman and London: University of Oklahoma Press, 1962. Kathy M'Closkey, Swept Under the Rug: a Hidden History of Navajo Weaving,(Albequerque: University of New Mexico Press, 2008).

${ }^{5}$ M'Closkey, 43.
} 
The climate patterns of the late $19^{\text {th }}$ and early $20^{\text {th }}$ centuries led to a period of accelerated erosion in the Southwest. Severe drought followed by an intense wet period contributed to a sensitive and brittle landscape while intensive grazing made way for invasive plants and increased aridity. In 1933, the BIA and the Soil Conservation Service began a series of herd reduction programs, intended to reduce the strain on the landscape by bringing the number of animals into balance with the land's resources. Due to poor planning and a lack of basic understanding of the role of livestock in Diné culture, the program was unnecessarily violent and traumatic, deepening Diné distrust of the federal government and contributing to an ongoing pattern of landscape erosion in the Navajo Nation. In the years following livestock reduction, the federal government embarked on breed-improvement programs, designed to increase the marketability of Navajo-raised wools. The churro sheep, so well-suited to life with the Navajo, produced wool incompatible with the demands of industrial processing. In 1934, the USDA created the Southwestern Sheep Breeding Laboratory in an effort to develop a cross-breed which would thrive in the Southwest while producing a more marketable wool. Through the combination of livestock reduction and 'breedimprovement' efforts, the Navajo-Churro sheep was all but decimated by the 1970s. Due to conservation efforts in the mid 1970s and the creation of the Navajo-Churro Sheep Association in the 1980s, the breed has been stabilized in recent years and has seen growing appreciation as a heritage breed.

Through the second half of the twentieth century, Diné continued to raise sheep primarily on a subsistence scale. It's difficult to get accurate numbers for wool production in the Navajo Nation, but figures from Arizona and New Mexico (below) give a general picture of the arc of $20^{\text {th }}$ century wool production. ${ }^{6}$ Wool sales were generally limited to a handful of trading posts on and around the reservation. These buyers (Teec Nos Pos, Cowtown of Gallup, Navajo Shopping Center, among others) generally resold the reservation wool to Roswell Wool of Roswell, New Mexico, one of the larger wool warehouses in the West. With the trading posts acting as middlemen and little value placed on churro and churro-related wools, prices remained stagnant.

\section{Number of Head of Sheep Shorn, New Mexico \& Arizona, 1909-2019}



Data from the USDA National Agricultural Statistical Service

\footnotetext{
${ }^{6}$ New Mexico generally has more non-Navajo (Anglo and Hispanic) ranchers and most of the wool raised on the Arizona side of the Navajo Nation is sold to trading posts in New Mexico, accounting for some of the volume distribution pictured here. Additionally, a byzantine grazing system and distrust of the federal government cemented by the livestock reduction programs result in a major under-counting of livestock in the Navajo Nation generally.
} 
Black Mesa's Navajo Wool Market Improvement Project emerged in response to these histories and conditions. By inviting buyers to the Navajo Nation to purchase wool, they bypassed the trading posts and gave producers access to the wider national wool market. BMWC and the Diné College Land Grant office hosted workshops and seminars for Diné producers, sharing best practices of fleece preparation, shearing, herd management. Depending on the type of wool, prices paid to producers have doubled or tripled since 2012. Additionally, the presence of the Wool Buy has led some trading posts to stop buying wool altogether or to start paying based on grade, thereby raising prices. For many involved in the Wool Buy, the end goal was to establish a wool-grading warehouse in the Navajo Nation, offering more flexibility and agency to Diné producers and removing the intermediate buyers from the equation altogether.

\section{THE WOOL BUY: WHAT IT’S LIKE}

Each day of the Wool Buy, the crew would pull up the site, usually the town rodeo grounds or chapter house parking lot, around 7:30am to be greeted by a line of cars, sometimes 40-60 deep, each loaded down with wool. We'd set up the tent, the scales, folding tables and bag stands and start checking people in and moving them through the line. Producers' loads ranged in size from a few fleeces (40-odd pounds wrapped in a bedsheet or packed in trash bags) to big flocks (a couple hundred pounds stacked high in burlap wool bags). As sellers pulled up to the front of the line, a team of people would unload the wool and Stanley from Mid-States would cut a hole in the side of the bag, grab a handful of wool and look at the color, the strength, the cleanliness. He'd identify the fiber diameter and staple length by sight and feel. He'd estimate its yield, or what portion of the fleece's weight was usable wool versus grease or dirt. Based on all this, he'd name a price, the lot would get weighed, and the seller would get their check.


Waiting in line, Tuba City Arizona; Wool in the sun, Shiprock New Mexico; June 2019. Photos by the author

The issue of grade is one primary tensions of the Wool Buy-finer, crimpier white wools command higher prices in the commercial wool market. ${ }^{7}$ However, a good portion of the wool

\footnotetext{
7 There's little demand for black wool at the industrial scale, as it can't be dyed uniformly. Finer wools make finer yarns which in turn make higher-end apparel commanding higher prices. Additionally, there is little incentive for U.S. producers to grow coarser wools as the costs of raising, shearing, handling wool remain consistent regardless of wool type and U.S. producers can't compete on labor costs with the global range of coarse wool producers.
} 
coming into the Buy is Churro-cross: it comes from sheep with a combination of churro and some other breed's genetics, resulting in wool that is neither fully Churro nor commercially valuable. The Diné College Land Grant program, led by Felix Nez, runs a ram rental program to help people introduce more marketable genetics into their flocks and while there are some Diné producers who raise wool at a larger and more commercially-oriented scale, the majority of producers are bringing in the wool they have around. Most people selling at the Buy are not raising wool with the express intention of making as much money as possible off of it - they are selling it because they have it, because they may not have the time or interest to process it themselves, because it may bring in some extra income. ${ }^{8}$ The churro-cross wool presents a particular challenge to the buyers, as the very traits that made the Navajo-Churro so well-suited to life with the Navajo make it quite unsuitable for industrial processing. The two separate coats - outer long and straight, inner, soft and crimpy — don't lend themselves to the monotony of industrial processing. The great natural palette of color is all labeled 'black' and sold for 5 cents a pound. This divergence between commercially-viable wools and wools characteristic of a more traditional Diné pastoralism highlights an underlying tension of the Wool Buy-how is value perceived and assigned and how is that reflected in the spectrum of prices? What are the gaps in those assignments of value? While commercial viability has obvious benefits (higher prices mean a more robust income stream to producers), it's worth noting that the criteria which determine the most sought-after characteristics in a fleece are anything but inevitable. They are shaped by a set of conditions which grows out of the demands of industrial capitalism.

Once purchased, these garbage bags of wool are thrown into an ever-growing pile next to the semi-truck and the rebagging begins. In previous years, the various volumes and densities of wool were tossed onto the truck as they came in, an exercise in nook-finding and crannysqueezing. This, of course, resulted in somewhat less than efficient packing, with about 19,000 pounds of wool to a truck. ${ }^{9}$ In 2019, looking to streamline the operation, Mid-States decided to rebag the wool before it was loaded. A trio of bag stands were set up in the shade of the semitruck and the packing crew began the work of ripping open bags of wool and tossing them up to the stomper who would dump the bag's contents into the big wool bag then jump in after them (being careful, of course, to jump in only when the wool volume was substantial enough to ensure they wouldn't get stuck, standing unhoistable, at the bottom of the bag). The stomper would jump vigorously on the wool, using the rim of the bag stand to increase the impact of their stomp and stabilize them as they rotated around the bag's perimeter. ${ }^{10}$ When the stomper felt that strata was sufficiently stomped, they'd hoist themselves out of the bag and perch back on the side of the stand to dump the next mound of wool in.

\footnotetext{
${ }^{8}$ These observations are based on conversations I had with producers while 'walking the line,' checking people in as they waited to sell at the 2019 Wool Buy. The economics of the Wool Buy defy reductive profit motive interpretations - people may wait in line for 4 hours to sell $\$ 50$ worth of wool, representing a year's worth of care, shepherding, shearing. There is much more at stake in people's decisions to sell than a simple time = money equation. Future fieldwork on this project will involve a return trip to the Navajo Nation for more in-depth conversations with Diné producers to better explore these questions.

${ }^{9}$ In contrast, a truck loaded with hydraulically-packed square bales carries 44,000 pounds of wool.

${ }^{10}$ In Stanley's words, "tromp the sides and the center will take care of itself..."
} 

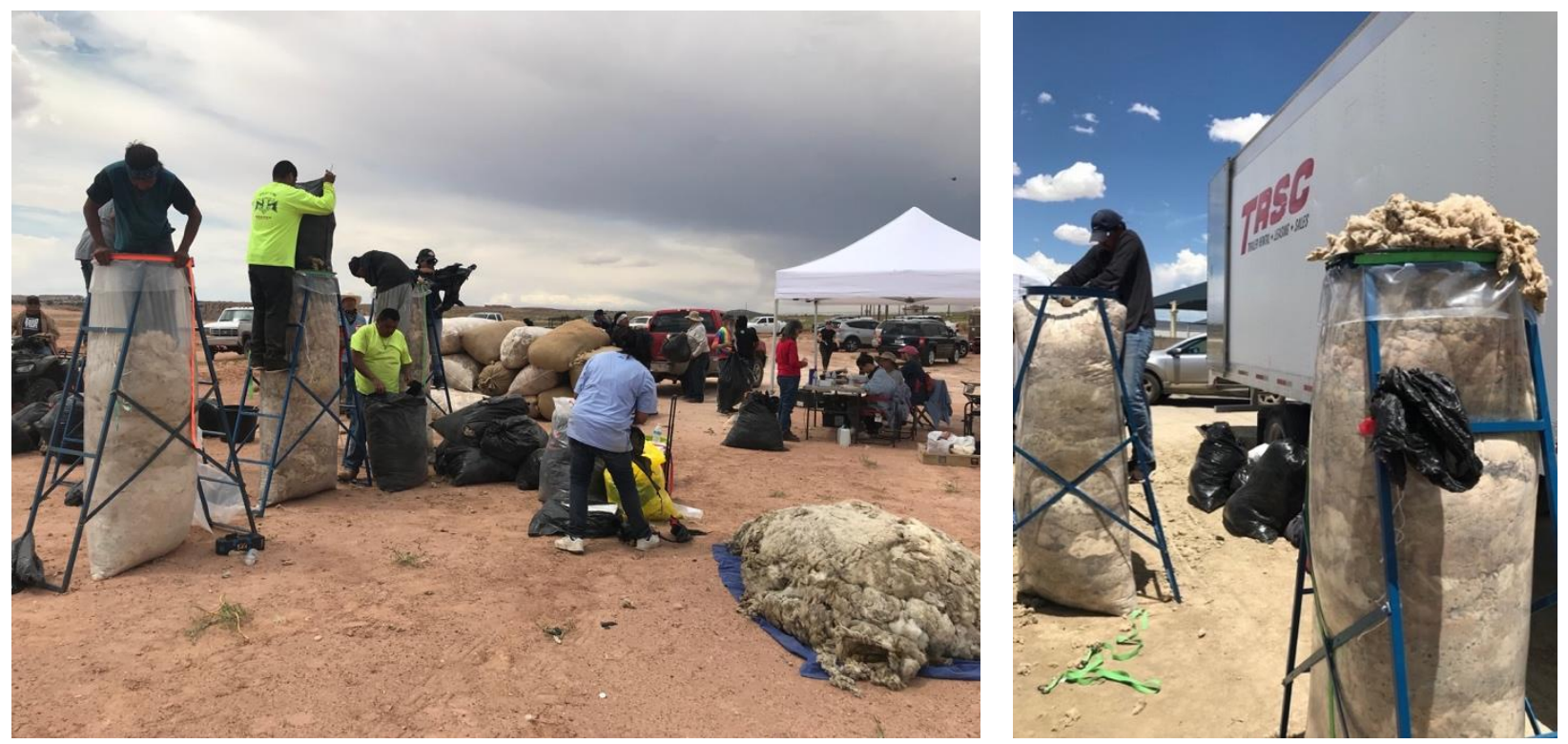

Stomping and loading wool bags, Tuba City, Arizona; Sewing a full bag, Shiprock New Mexico; June 2019. Photos by the author

Once this bag was filled with approximately 180 pounds of wool, the stomper would hunt down one of two or three enormous needles floating around the work area and stitch the rolled top of the bag shut with twine. The guy on the ground would release the cross braces on the bag stand, jab at the 6 foot tall bag from its side until it dropped, with a thud, on the dirt. Two of the more sprightly baggers would drag it over to the back of the semi and heave it up into the truck. Two more folks inside the truck would carry on stacking bags like bricks, filling the crevices close to the ceiling with the occasional trash bag. This new method resulted in about 22,000 pounds of wool on a truck, up about 3,000 pounds from the previous method. With the more efficiently packed trucks, the cost of sending wool from the Navajo Nation to Ohio dropped from about 18 to 15 cents per pound. In these early stages of the supply chain, the wool's volume and shape are its most-transformed qualities. It is packed into trash bags, it is unpacked, it is compressed into wool bags. Value accrues with each expansion and contraction of the material.

In the course of transforming raw material into object, some processes are more visible to us than others. These steps - shearing, spinning, weaving, tailoring — could be understood as transformation writ-large. They are the processes in which we can clearly see how productive human labor is brought to bear on a raw material, bringing it towards a state of usefulness and exchangeability. These processes, however, represent only a portion of the labor which moves raw material into form. They are supplemented by what we could call transformation writ-small: the processes, like wool-stomping, which are integral to the manufacturing process yet remain less than visible. Glenn Adamson's formulation of the supplemental nature of craft with respect to art offers a framework for understanding the necessary and invisible nature of this type of work: "To say that craft is supplemental, then, is to say that it is always essential to the end in view, but in the process of achieving that end, it disappears... proper craftsmanship draws no attention to itself; it lies beneath notice, allowing other qualities to assert themselves in their fullness." 11 The acts of wool-stomping and wool-bagging exemplify this idea of the

\footnotetext{
${ }^{11}$ Glenn Adamson, Thinking Through Craft, (Oxford: Berg, 2007), 13.
} 
supplemental — an incredibly laborious, time-consuming and specific activity which requires skill and finesse but is far less visible than certain other types of material transformation. By the end of the week, 160,000 pounds of wool were packed onto seven 50-foot semi-trucks and sent to the Mid-States warehouse.

\section{MID-STATES WOOL GROWERS}

The Mid-States Wool Growers Cooperative warehouse is located in Canal-Winchester Ohio, about 15 miles southeast of Columbus. The building consists of a small flat-roofed entry containing the front office and retail store tacked onto the gable side of a much larger building with a gently sloping peaked roof. Receiving sits under one of those eaves, Shipping below the other. The warehouse was built in 1995, its main feature being an overhead computerized woolsorting system adapted from the auto industry. The company was started in 1918, as the Tri-State Wool Growers, by a group of producers who pooled their wool in an effort to get higher prices during World War I. They purchased their first warehouse a few years later, and over the next few decades went through several name-changes and consolidations with other cooperatives.
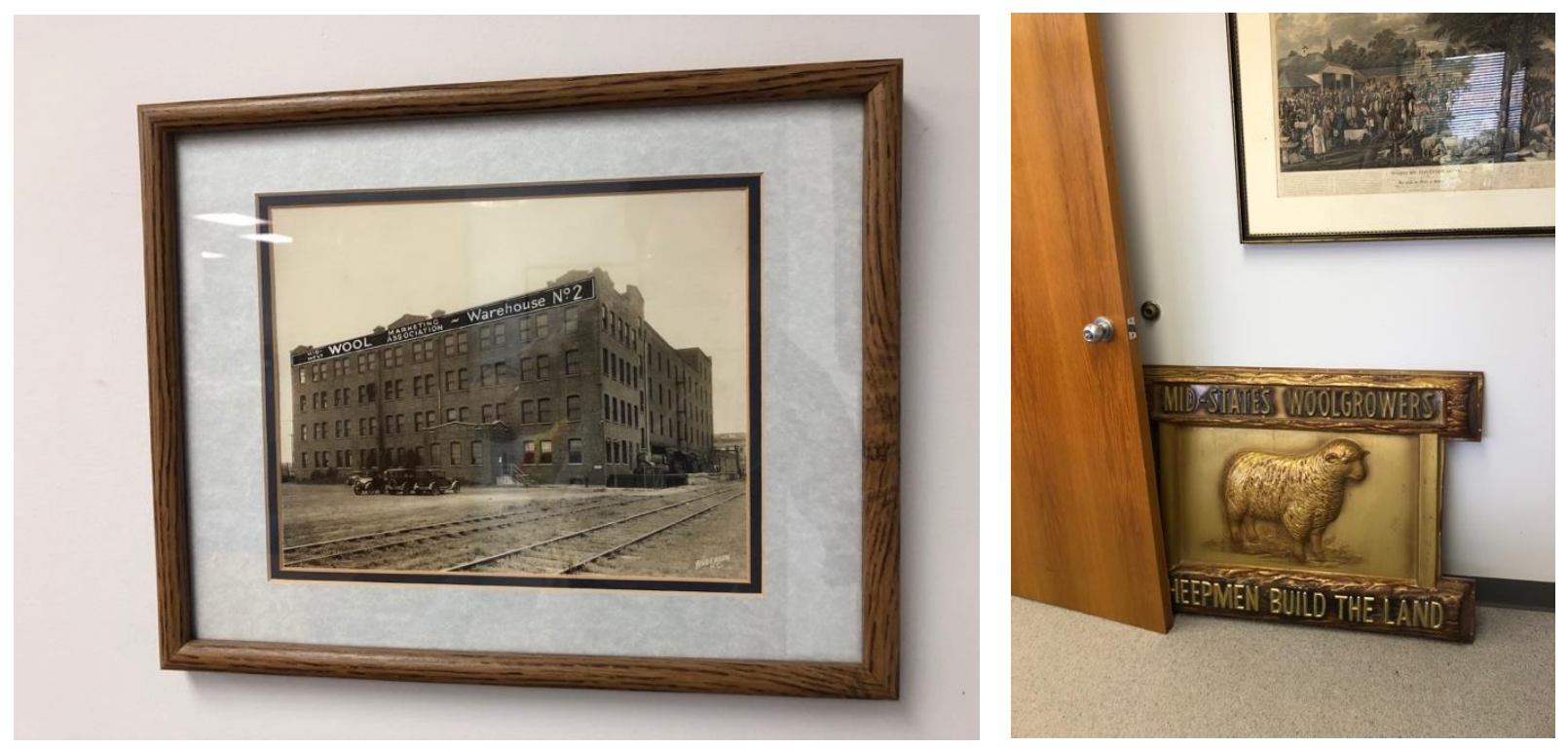

Photograph of the historic Columbus Mid-States warehouse; Mid-States sign, August 2019. Photos by the author

As the domestic wool industry has contracted in recent decades (dropping from 45 million sheep shorn in 1939 to less than 3.5 million in 2019) due to a complex of factors including decrease in demand and overseas competition, Mid-States has expanded their buying territory to source the volume needed to keep the operation viable. Today Midstates moves about 1.3 million pounds of wool through the warehouse annually, purchased from producers all over the country. In 2019, the Navajo clip made up about $12 \%$ of that annual volume. They operate primarily on a cooperative model in which individual producers consign their wool to Mid-States, pooling with other producers to get better prices than they could on their own. Some portion of the Navajo wool is bought on consignment but most is purchased on the weigh and pay model, where producers are paid upfront at the moment of sale based on the grader's estimate of what the wool will sell for. This results in slightly lower prices per pound, but with over 800 producers selling 
mostly small lots at the Wool Buy, simply keeping track of what wool belonged to which producer would be an impracticable task.

\section{Number of head of sheep shorn in the United States 1909-2019}

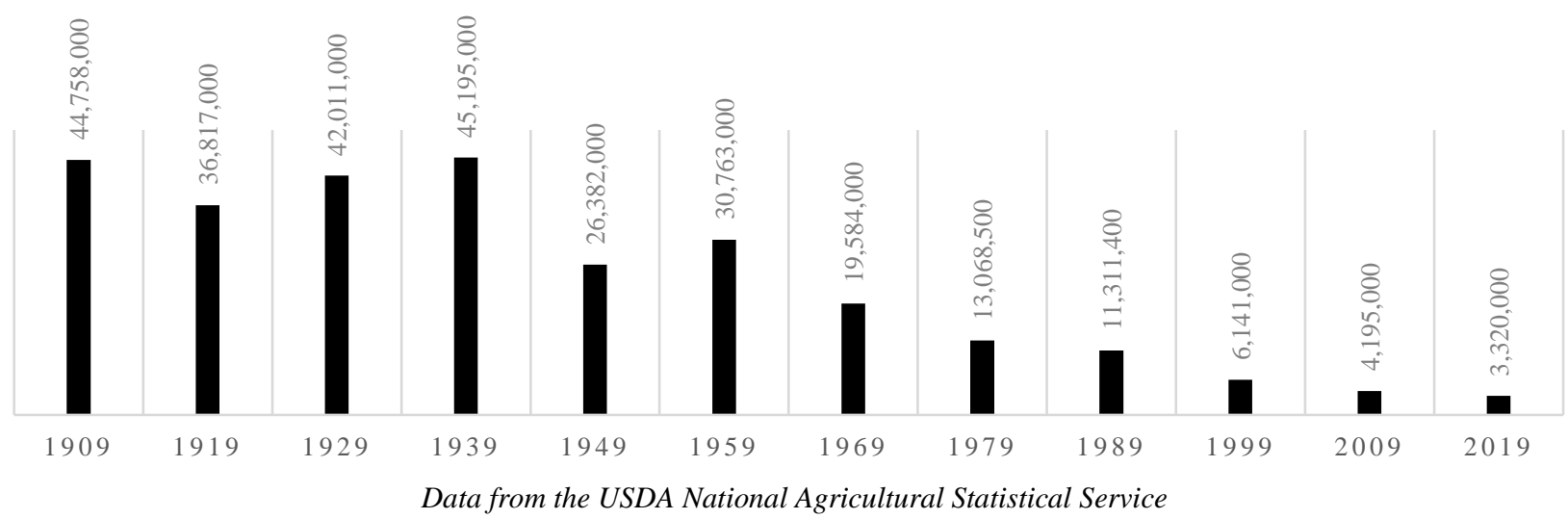

Mid-States is fundamentally a sorting and packing operation: wool bags come in on the receiving side and are unloaded onto the conveyor belt at the entrance to the grading floor. They travel up the conveyor belt to the grading station, a work-station perched at the top of a narrow staircase, to be received by the wool grader. He looks at the fleece, lifting it to sense its yield, pulling it apart to see the size of the fibers. At this point in the process, there are no non-human instruments or tools involved in evaluation - the grader is making decisions based wholly on sense and experience acquired through the handling of many thousands of fleeces. He assigns it a grade and slides it into one of the metal baskets rocking back and forth beside the grading station. These baskets, hanging from a track that traces the perimeter of the grading floor, are at the vanguard of wool-sorting technology. As the fleece slides from the grading station to the basket, the grader hits a button on the console, telling the basket what section of the warehouse the wool should be dropped. The basket continues on its path around the warehouse until it reaches the designated bay and the basket is tripped by a sensor overhead. The basket flips backwards and the fleece drops onto the mountain of wool below.
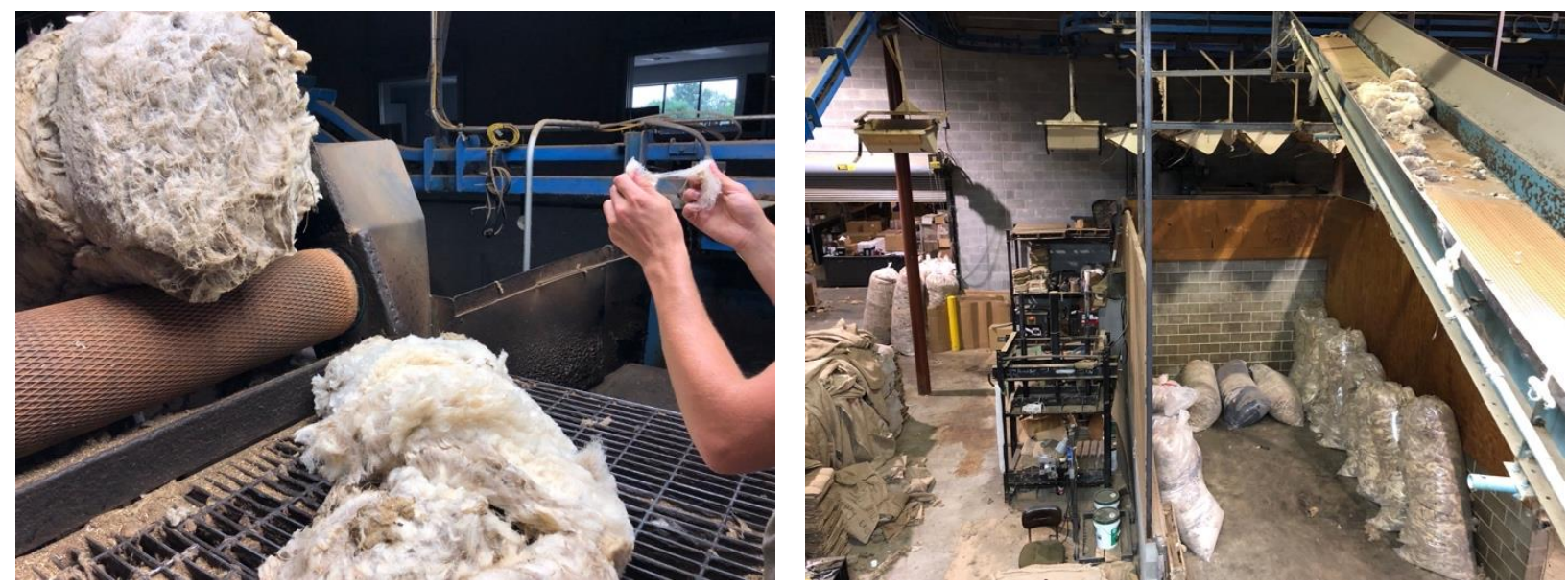

Grading wool; the basket system as seen from the grading station, Mid-States warehouse, August 2019. Photos by the author 
The seven semi-loads of Navajo clip arrived at the Mid-States warehouse in June 2019 and were unpacked and stacked against a wall in the warehouse where they would sit until shearing season and the stream of wool coming in from across the country slowed down. At this point, the Navajo clip would cease to exist as a lot with a specific origin but would be disaggregated, its various wools combined with like wools from other producers, baled and shipped off to MidStates primary customer, Chargeurs USA.
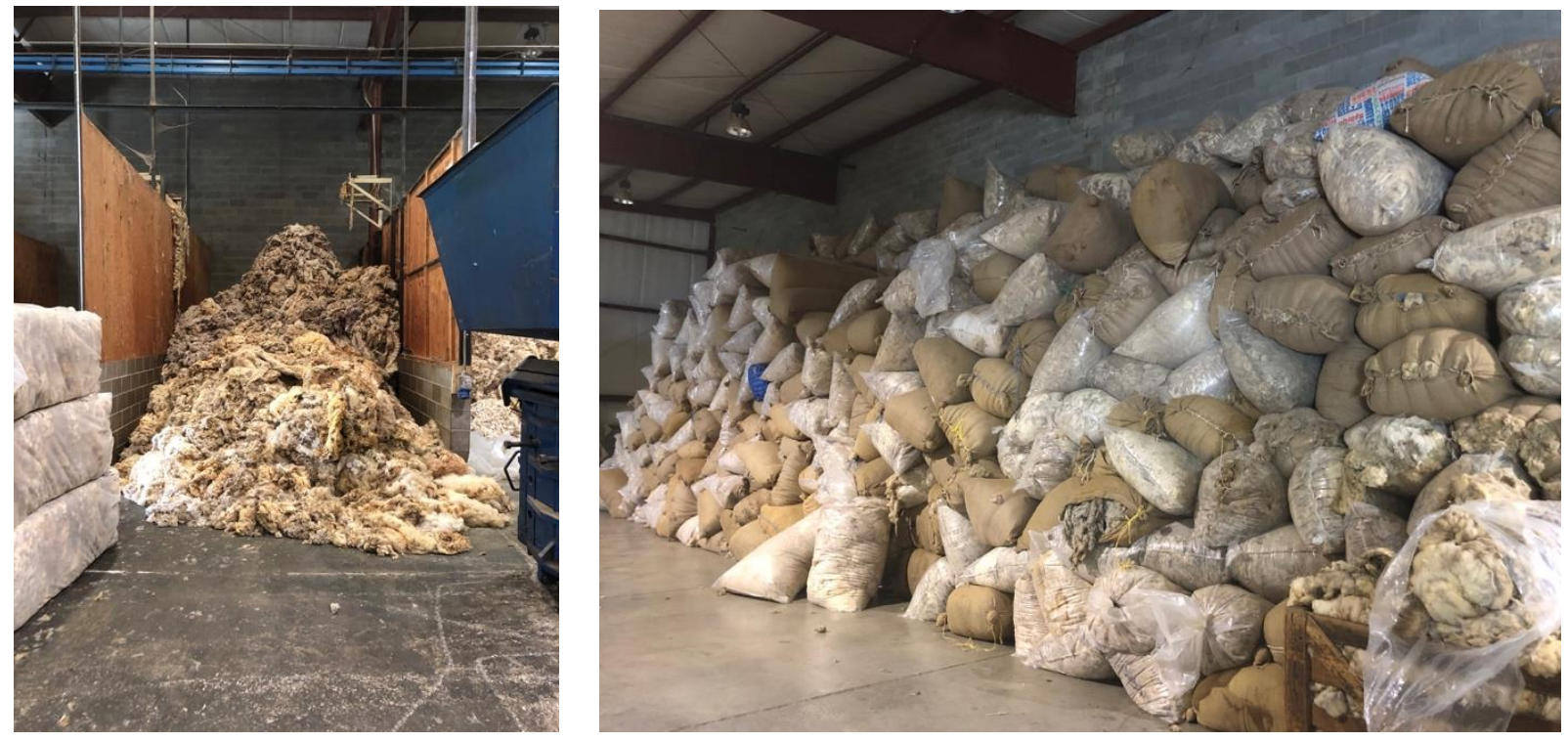

A bay of graded wool waiting to be baled; a portion of the 2019 Navajo clip at Mid-States, August 2019. Photos by the author

\section{CHARGEURS USA}

By the time the wool arrives at the Chargeurs plant in Jamestown, South Carolina, its transformation from raw material with a specific and discernable origin into material that can circulate in the global wool market is almost complete. Scouring, the process of washing wool to remove grease, lanolin, vegetable matter, dirt and dust, is a water-intensive process requiring much space and water supply. Once scoured, the wool is turned into top: the fibers are combed so that they lie parallel and are ready to be spun into yarn. Chargeurs Luxury Materials, a subsidiary of French multi-industrial company Chargeurs International, bought the Santee River Combing Company, a scouring operation founded in 1955, in the 1990s. Today, Chargeurs USA moves between 10-12 million pounds of wool through their plant each year, the majority of which is bought from wool warehouses around the country and sold to various customers, mostly domestic spinning mills. As the only scouring and combing operation in the U.S., all domestically produced wools for the worsted system pass through their plant. ${ }^{12}$

When wool arrives at the plant, the bales are opened up and put through a picker, where the compressed wool is pulled apart and blended to a state of uniformity. It then enters the scouring train, a long, loud, steamy series of baths in which a combination of detergent and hot water removes dirt, dust and grease. The grease and lanolin are extracted from the waste-water and

\footnotetext{
${ }^{12}$ There is one other major scouring plant in the United States: Bollman of San Angelo, Texas, but as a scouringonly operation, they fill a different niche in the domestic textile landscape.
} 
sold as by-product for use in various industries. The clean wool is then taken through a series of combing operations, culminating in large bobbins of wool top. Chargeurs scours an average of 50,000-60,000 pounds of wool a day.


Wool bale ready to be opened up; Wool coming out of the dryer; Wool in the process of combing; Finished bobbins of wool top at Chargeurs USA,October 2020. Photos by the author

Most wool is sold (and traded as a commodity on the wool futures market) on a 'clean' basis with prices figured in relation to the prices given at the Australian Wool Exchange's weekly auctions. ${ }^{13}$ All the actions performed upon the wool to bring it to this point (shepherding,

\footnotetext{
${ }^{13}$ Wool can be sold on a greasy basis but this is less common as it involves more risk for both buyer and seller. Prices are much lower per pound as they account for the grease, dirt, plant matter that will be removed in the scouring process which could account for over half the wool's weight. Clean wool is generally sold with a core-test report, an analysis done by a laboratory certifying various characteristics of the wool. As the primary global wool
} 
shearing, skirting, packing, sorting, transporting, grading) are contained in its 'clean' price. It is in relation to this clean price that all the preceding labor is valued, a series of calculations based not on time or resources expended, but on prices fetched at auctions held in Melbourne and Sydney. This segment of the supply chain - all the activity that brings the wool to its clean state - exists in what I would consider a state of pre-articulation. The material is not yet discernable as product in the global wool market. This reinforces the point that prices, seductive in their quantitative clarity, are only loosely tethered to the resources, time, and energy that bring raw material to exchangeable form. Furthermore, they are figured not with respect to the needs of producers but in relation to abstract market forces.

\section{CONCLUSION}

In the essay "Marx's Coat", literary critic Peter Stallybrass explores the ways in which the form of the fetish can be used to understand the embodiment of personality, history, memory in an object. The object which lives closely to the person, which holds some power over them, is specific and particular. This is in contrast to the commodity-fetish, which is by definition an abstraction defined by its exchangeability, the possessor of a "transcendental value that erases both the making and the wearing of the coat." 14 Stallybrass argues that the fetish itself is not the problem for Marx, it's the fetishization of the commodity that is troubling. The process of exchange involves the conversion of specific historical processes and realities into ahistorical transcendent abstractions. It erases history and specificity as it attempts to equate the incommensurate. This fact results in the alienation of workers from the products of their labor, as those products exist as manifestations of their labor itself.

Wool — an animal fiber whose material qualities reflect the climate, landscape and conditions in which it is raised-is transformed through manufacturing processes into useful objects. As the material changes hands over and over again, moving down the supply chain, its corresponding price rises to reflect the labor and movement bringing it to that point. As raw material becomes more comprehensible as a useful material, little remains to tell us about where it has come from, the places it has been, what conditions (both local and global) shape its transformation and existence. According to Stanley Strode, the biggest wool contaminant is no longer kemp (coarse white brittle fibers which don't accept dye) but poly rope. This springy blue or sometimes yellow rope shows up in wool bags and if not removed, wreaks havoc on wool processing equipment. Sometimes a rope fragment will somehow make it through scouring, combing and spinning to appear twisted in with the fibers of the wool yarn that I work with. This rope fragment, while nominally a 'fault,' is the only material evidence of the wool's origins that accompanies the raw material as it continues on its path towards objecthood.

producer, Australia determines price and quality standards and U.S. wool prices are figured as a percentage of Australian prices. Depending on the type of U.S. wool, its price might be figured at 70-90 percent of the price of a comparable Australian wool. When the wool market is depressed, as it has been in 2020, the demand for lower quality wool disappears as prices on high quality wools go down.

${ }^{14}$ Peter Stallybrass, "Marx's Coat," In Border Fetishisms: Material Objects in Unstable Spaces, edited by Patricia Borden, (Abingdon: Routledge, 1998), 187. 


\section{0: COVID-19 ADDENDUM}

The coronavirus crisis has, unsurprisingly, had a severe impact on the wool industry. The Navajo Nation was incredibly hard hit by Covid-19 and the 2020 Wool Buy was cancelled, leaving Diné producers with the local trading posts and livestock depots as their options for selling wool. Diné College sent one load (about 20,000 pounds) of fine wool from some of the larger producers to Mid-States over the summer. Chargeurs shut down in late March 2020 and didn't restart the scouring line until mid-July. With Chargeurs closed, Mid-States had nowhere to send their wool but continued receiving and grading wool as it arrived from producers. They began taking wool on consignment only and stopped taking any coarser, lower-quality or colored wools that are harder to sell. Prices plummeted globally and had yet to rebound significantly by early 2021 .

Wool prices paid direct to Diné producers (by the pound), 2019 Wool Buy vs 2020 alternatives

\begin{tabular}{r|c|c|c|c} 
& $\begin{array}{c}2019 \text { Wool Buy } \\
\text { averages }\end{array}$ & $\begin{array}{c}\text { Teec Nos Pos } \\
\text { Trading Post } \\
\text { July 2020 }\end{array}$ & $\begin{array}{c}\text { Cowtown Feed \& } \\
\text { Livestock } \\
\text { Gallup, NM } \\
\text { July 2020 }\end{array}$ & $\begin{array}{c}\text { Navajo Shopping } \\
\text { Center } \\
\text { Gallup, NM } \\
\text { July 2020 }\end{array}$ \\
\hline White wool & $\$ 0.47-\$ 0.65$ & $\$ 0.15-\$ 0.25$ & $\$ 0.03-\$ 0.30$ & $\$ 0.15$ \\
\hline Churro & $\$ 0.15-\$ 0.40$ & $\$ 0.01$ & $\$ 0.03$ & $\mathrm{n} / \mathrm{a}$ \\
\hline Black wool & $\$ 0.05$ & $\$ 0.01$ & $\$ 0.03$ & $\$ 0.02$ \\
\hline White mohair & $\$ 1.50-\$ 2.00$ & $\$ 0.50$ & $\$ 0.25$ (dirty) $-\$ 0.50$ & $\$ 0.60$ \\
\hline Black mohair & $\$ 0.70$ & $\$ 0.20$ & $\$ 0.15$ & $\$ 0.30$
\end{tabular}

\section{BIBLIOGRAPHY}

Adamson, Glenn. Thinking Through Craft. Oxford: Berg, 2007.

Amsden, Charles Avery. Navaho Weaving: its technic and history. Glorieta New Mexico: The Rio Grande Press, 1971.

Collins, Jane L. Threads: Gender, Labor, and Power in the Global Apparel Industry. Chicago: University of Chicago Press, 2003.

Hart, Peggy. Wool: Unraveling an American Story of Artisans and Innovation. Atglen Pennsylvania: Schiffer Publishing, 2017.

Marx, Karl. Capital: Volume One. New York: Vintage Books, 1977.

M'Closkey, Kathy. Swept Under the Rug: a Hidden History of Navajo Weaving. Albequerque: University of New Mexico Press, 2008.

McNitt, Frank. The Indian Traders. Norman and London: University of Oklahoma Press, 1962. National Research Council. Changes in the Sheep Industry in the United States: Making the Transition from Tradition. Washington, DC: The National Academies Press, 2008. 
Powell, Dana E. Landscapes of Power: Politics of Energy in the Navajo Nation. Durham: Duke University Press, 2018.

Roessel, Ruth and Broderick H. Johnson, editors. Navajo Livestock Reduction: A National Disgrace. Chinle, AZ: Navajo Community College Press, 1974.

Stallybrass, Peter. "Marx's Coat.” In Border Fetishisms: Material Objects in Unstable Spaces, edited by Patricia Borden. Abingdon: Routledge, 1998, 183-207.

"Statistics by Subject: National Statistics for Wool," USDA National Agricultural Statistics Service, accessed October 2020, https://www.nass.usda.gov/Statistics_by_Subject/result.php?532A84FB-1AA6-3F29A14C1B8C8C36D62D\&sector=ANIMALS\%20\%26\%20PRODUCTS\&group=LIVESTOCK\& comm $=$ WOOL

Weisiger, Marsha. Dreaming of Sheep in Navajo Country. Seattle: University of Washington Press, 2009.

Weisiger, Marsha. "Gendered Injustice: Navajo Livestock Reduction in the New Deal Era." The Western Historical Quarterly 38, no. 4 (2007): 437-55.

Wentworth, Edward Norris. America's Sheep Trails: History Personalities. Ames Iowa: Iowa State College Press, 1948. 